\title{
STUDY ON THE PHYSICOCHEMICAL AND CHEMICAL PARAMETERS OF DRINKING AND SURFACE WATERS FROM MINE AREA AT VILLAGE BOV, BALKAN MOUNTAIN, BULGARIA
}

\author{
METODI MLADENOV ${ }^{a,}$, IRINA KARADJOVA ${ }^{b}$, \\ GALIA GENTSCHEVA ${ }^{c, d}$, ALBENA PREDOEVA $^{\mathrm{e}}$
}

\begin{abstract}
Water quality is influenced by natural local climate, geology and anthropogenic effects. In the present study, surface waters in hydrographic area, situated in mining region, in the vicinity of abandon copper mine, are characterized and their quality assessed from the view point of the requirements of European Water Frame Directive and Drinking Water Directive. Three sampling campaigns starting at 2012 from 16 sampling sites, in different seasons were performed in order to evaluate both natural, seasonal variations connected with water regimes and anthropogenic pressures. Chemical elements (Al, As, Ba, Cd, Cr, Co, Cu, Fe, Hg, Mn, Ni, Pb, Se, U, V, Zn and lanthanides) and physicochemical parameters $(\mathrm{pH}$, conductivity, hardness, chemical oxygen demand ( $\left.\mathrm{COD}_{\mathrm{KMnO}}\right)$; biological oxygen demand $\left(\mathrm{BOD}_{5}\right)$; dissolved oxygen; dissolved solids; suspended matter; dry residue; chlorides; sulphates; nitrates; phosphates) were measured for characterization and evaluation of different water sources in the region. Conclusions for the further use of waters from this region as tap waters were presented and validated through the determination of much more chemical elements than these required from national legislation.
\end{abstract}

Keywords: surface water, drinking water, chemical element, physicochemical parameter, ICP-MS.

a University of Chemical Technology and Metallurgy, Department of Engineering Ecology, 8 St. Kliment Ohridski blvd., Sofia, Bulgaria.

b University of Sofia, Faculty of Chemistry and Pharmacy, 1 James Bourchier blvd., Sofia, Bulgaria.

c Medical University-Pleven, Department of Chemistry and Biochemistry, 1, Sv. Kliment Ohridski Str., Pleven, Bulgaria.

d Institute of General and Inorganic Chemistry, Bulgarian Academy of Sciences, Akad. G. Bonchev Str, BI. 11, Sofia, Bulgaria.

e Research Institute of Forensic Science and Criminology, 1 Aleksander Malinov blvd., Sofia, Bulgaria.

* Corresponding author: mladenov@uctm.edu 


\section{INTRODUCTION}

European Water Frame Directive [1] requires classification of surface waters in member states, based on the assessment of their ecological and chemical status. On the other side in some cases same surface waters are used as only source of drinking water for the people living in the same area and in this case quality standards of Drinking Water Directive should be taken into account [2].

In this study results from three monitoring campaigns of surface waters near the village Bov, are presented. Also, very often themselves sources used for drinking water, are reservoirs (or other type of intake) and control their maintenance is lowered. Main problem is the classification of the tested waters. In such places often, a surface water source is also used as drinking and precisely where the difficulty comes in the classification of water sources and conducting a further monitoring. In such cases, the question is which rules and regulations to implement: surface water [8] - With a view to environmental monitoring or drinking water $[9,10]$ - in order to ensure safety for the population?

Many similar studies [11-16] in which the element concentration, mainly of heavy metals are examined, it have, but the authors cannot find studies in which the hydrological regime to be taken into account.

As a result characterization of surface and drinking water sources in the area of Bov as well as dynamics of the changes in their composition in an extended period of time, and depending on the hydrological regime in the area will be presented.

\section{RESULTS AND DISCUSSION}

\section{Physicochemical parameters}

However, results obtained for surface waters do not confirm good ecological status especially for sampling points situated downstream after cities and parameters such as - biological oxygen demand and dissolved oxygen. It is worth mention that relatively different values were accepted as permissible limits for physicochemical parameters for drinking waters which were derived on the basis of human health safety and for surface waters derived on the basis of health and biodiversity of aquatic organism [8]. That is why different classification of waters might be obtained taking into account their different use and application.

Results for physicochemical parameters for all studied samples, for all sampling campaigns are below the permissible limits $(\mathrm{pH}=6,5-9,5$; conductivity $-2.10^{-3} \mu \mathrm{S} / \mathrm{cm}$; hardness -12 mgeq. $\mathrm{dm}^{-3}$; P-total $-0.5 \mathrm{mg} . \mathrm{dm}^{-3}$; $\mathrm{N}-\mathrm{NO}_{3}-30 \mathrm{mg} \cdot \mathrm{dm}^{-3} ; \mathrm{COD}_{\mathrm{KMnO}}-5.0 \mathrm{mg} \cdot \mathrm{dm}^{-3} ; \mathrm{SO}_{4}{ }^{2-}-250 \mathrm{mg} \cdot \mathrm{dm}^{-3}$ ) accepted as national standards for drinking waters 
As an example, the $\mathrm{pH}$ values obtained for drinking waters during the three sampling campaigns are given in Table 1. Statistically insignificant differences between results undoubtedly show no any influence of hydrological regime. Almost identical results were obtained for all other studied physicochemical parameters [10]. However, results obtained for surface waters do not confirm good ecological status especially for sampling points situated downstream after cities and parameterc such as - biological oxygen demand and dissolved oxygen. It is worth mention that relatively different values were accepted as permissible limits for physicochemical parameters for drinking waters which were derived on the basis of human health safety and for surface waters derived on the basis of health and biodiversity of aquatic organism [8]. That is why different classification of waters might be obtained taking into account their different use and application.

Table 1. $\mathrm{pH}$ values obtained for drinking waters.

\begin{tabular}{|c|c|c|c|c|c|c|c|c|c|c|c|c|c|}
\hline \multirow{2}{*}{\multicolumn{2}{|c|}{$\mathrm{pH}$}} & \multicolumn{11}{|c|}{ Sample number } & \multirow{2}{*}{$\begin{array}{l}\text { Permissible } \\
\text { range }\end{array}$} \\
\hline & & 5 & 6 & 7 & 8 & 9 & 10 & 11 & 12 & 14 & 15 & 16 & \\
\hline \multirow{3}{*}{$\begin{array}{c}\text { Sampling } \\
\text { campaign } \\
\text { (SC) }\end{array}$} & A & 8.15 & 7.83 & 8.07 & 7.85 & 7.94 & 7.96 & 8.11 & 7.98 & 7.07 & 7.52 & 7.58 & \multirow{3}{*}{$6.5-9.5$} \\
\hline & B & 8.04 & 7.72 & 7.91 & 7.78 & 7.92 & 7.78 & 7.93 & 8.01 & 7.08 & \begin{tabular}{|l|}
7.49 \\
\end{tabular} & 7.58 & \\
\hline & C & 8.10 & 7.04 & 7.22 & 7.14 & 6.99 & 7.20 & 7.53 & 7.32 & 7.06 & 7.48 & 7.56 & \\
\hline
\end{tabular}

\section{Chemical elements content}

Results obtained for elements (Al, As, Ba, Cd, Cr, Co, Cu, Fe, Mn, $\mathrm{Ni}, \mathrm{Pb}, \mathrm{Se}, \mathrm{U}, \mathrm{V}, \mathrm{Zn}$ ) content in all studied sampling sites (without local springs) are depicted in Table 2. The concentrations measured for $\mathrm{Hg}$ are close to their natural levels and much below the permissible limits for surface and drinking waters and are not included in Table 2. The same is valid for lanthanides; these elements were included in the present study because elevated concentrations might be expected near the abandon copper mine. However determined concentrations are very close to natural background levels in surface and spring waters.

\section{Surface waters}

Results obtained for priority pollutants $(\mathrm{Cd}, \mathrm{Hg}, \mathrm{Ni}$ and $\mathrm{Pb})$ and specific pollutants (Al, As, $\mathrm{Cr}, \mathrm{Cu}, \mathrm{Fe}, \mathrm{Mn}, \mathrm{U}$ and $\mathrm{Zn}$, accepted at national level) for surface waters were compared with accepted environmental quality 
standards at European level for priority pollutants and with accepted environmental quality standards at national levels for specific pollutants [8]. As can be seen both chemical and ecological status of surface water at sampling point 13 is bad taking into account elevated concentrations measured for priority pollutants $\mathrm{Cd}$ and $\mathrm{Pb}$ and specific pollutants $\mathrm{Cu}$ and $\mathrm{Zn}$. The influence of hydrological regime is evident as far as elements concentrations are statistically significantly lower for sampling campaign B in comparison with campaigns $\mathrm{A}$ and $\mathrm{C}$. However due to the natural dilution, concentrations measured at sampling points 3 and 4 are remarkably lower and good chemical and ecological status could be assigned for river Treskavets at all.

\section{Drinking waters}

As already mention the drinking water standard might be different from those for surface waters, taking into account the way of their derivation and the purpose of their application. Sampling site 13 is water catchment in mining gallery and might be accepted as a surface water (spring of river Trescavets) and in the same time as a source of drinking water. National legislation for quality control of drinking waters requires compliance with accepted permissible limits for $\mathrm{As}, \mathrm{Cd}, \mathrm{Cu}, \mathrm{Ni}, \mathrm{Pb}, \mathrm{Cr}, \mathrm{Se}, \mathrm{Ba}, \mathrm{V}, \mathrm{Fe}, \mathrm{Mn}$, $\mathrm{Zn}$, Co.

The main water supply for drinking and household needs of the population in the region is fed from the spring of river Treskavets (sampling site 13) and controlled by sampling sites 10 and 11 . As can be seen from the analytical results the concentration of $\mathrm{Pb}$ at the beginning is $70 \mu \mathrm{g} \mathrm{L}^{-1}$, which is much above the statutory drinking water limit under regulation 12 $10 \mu \mathrm{g} \mathrm{L}^{-1}$ [9]. The concentration of $\mathrm{Pb}$ in points 10 and 11 is three times lower, but still remain above the statutory limit. The values for all other chemical elements showed no deviation from the permissible limits. In early 2013 (B) source 13 is replaced by source 5 . The results obtained during the second sampling showed values for all elements which meet the regulatory requirements in all points. Unexpectedly, relatively high concentrations over the statutory limits were found for $\mathrm{Mn}$ at point 13 during the last sampling. Evidently the spring at point 13 is a source of high elements concentrations and when switching it with a source 5 in the second sampling campaign, significantly lower values were observed for most of the elements. It is worth mention however that concentrations at sampling points 10 and 11 are still higher than these in initial point 5 , which most probably is a sign that some elements accumulated in the pipeline network and still impact final concentrations. 
STUDY ON THE PHYSICOCHEMICAL AND CHEMICAL PARAMETERS OF DRINKING ...

Table 2. Element concentrations at every sampling point of the studied area (mean value, three parallel determinations)

\begin{tabular}{|c|c|c|c|c|c|c|c|c|c|c|c|}
\hline Element & SC & 1 & 2 & 3 & 4 & 5 & 13 & 10 & 11 & 9 & 16 \\
\hline \multirow{3}{*}{$\begin{array}{c}\mathrm{Al}, \\
\mathrm{gg} \mathrm{L}^{-1}\end{array}$} & $\mathbf{A}$ & 6.8 & 6.1 & 6.6 & 6.4 & 8 & 2.13 & 5.5 & 5.3 & 8.4 & 9.0 \\
\hline & B & 0.08 & $<0.05$ & $<0.05$ & $<0.05$ & $<0.05$ & 2.57 & $<0.05$ & $<0.05$ & $<0.05$ & $<0.05$ \\
\hline & C & 0.05 & $<0.05$ & $<0.05$ & 0.19 & $<0.05$ & 2.30 & 0.12 & 0.12 & $<0.05$ & $<0.05$ \\
\hline \multirow{3}{*}{$\begin{array}{l}\text { As, } \\
\mu \mathrm{g} \mathrm{L}^{-1}\end{array}$} & A & 1.58 & 1.86 & 0.89 & 1.21 & 0.12 & 1.78 & 1.3 & 1.4 & 0.95 & 0.9 \\
\hline & B & 3.8 & 2.97 & 0.91 & 1.27 & 0.09 & 1.81 & 0.28 & 0.18 & 1.03 & 1.02 \\
\hline & C & 6.36 & 3.32 & 0.77 & 1.53 & 0.13 & 1.94 & 0.97 & 0.99 & 1.51 & 1.47 \\
\hline \multirow{3}{*}{$\begin{array}{l}\mathrm{Ba}, \\
\mu \mathrm{g} \mathrm{L}^{-1}\end{array}$} & $\mathbf{A}$ & 25 & 65 & 100 & 95 & 16 & 106 & 63 & 62 & 56 & 56 \\
\hline & B & 32 & 102 & 101 & 99 & 15 & 112 & 15 & 17 & 56 & 52 \\
\hline & C & 43 & 144 & 129 & 115 & 18 & 120 & 69 & 67 & 66 & 67 \\
\hline \multirow{3}{*}{$\begin{array}{l}\mathrm{Cd}, \\
\mu \mathrm{g} \mathrm{L}^{-1}\end{array}$} & $\mathbf{A}$ & $<0.03$ & $<0.03$ & 0.03 & $<0.03$ & $<0.03$ & 1.97 & 1.11 & 1.08 & $<0.03$ & $<0.03$ \\
\hline & B & $<0.03$ & $<0.03$ & $<0.03$ & 0.03 & $<0.03$ & 1.97 & 0.14 & 0.06 & $<0.03$ & $<0.03$ \\
\hline & C & $<0.03$ & $<0.03$ & $<0.03$ & 0.04 & $<0.03$ & 2.24 & 1.17 & 1.13 & $<0.03$ & $<0.03$ \\
\hline \multirow{3}{*}{$\begin{array}{l}\text { Co, } \\
\mu \mathrm{g} \mathrm{L}^{-1}\end{array}$} & A & 0.25 & 0.26 & 0.19 & 0.21 & 0.22 & 20.3 & 10.98 & 11.08 & 0.23 & 0.25 \\
\hline & B & 0.43 & 0.44 & 0.33 & 0.36 & 0.34 & 21.1 & 0.53 & 0.44 & 0.37 & 0.39 \\
\hline & C & 0.41 & 0.41 & 0.39 & 0.42 & 0.25 & 24.4 & 12.01 & 12.07 & 0.44 & 0.48 \\
\hline \multirow{3}{*}{$\begin{array}{l}\mathrm{Cr} \\
\mu \mathrm{g} \mathrm{L}^{-1}\end{array}$} & $\mathbf{A}$ & 0.09 & 0.1 & 0.1 & 0.09 & 0.27 & 0.05 & 0.14 & 0.13 & 0.08 & 0.09 \\
\hline & B & 0.07 & 0.07 & 0.06 & 0.06 & 0.09 & 0.03 & 0.1 & 0.1 & 0.1 & 0.1 \\
\hline & C & 0.08 & 0.09 & 0.1 & 0.1 & 0.15 & 0.04 & 0.07 & 0.07 & 0.12 & 0.11 \\
\hline \multirow{3}{*}{$\begin{array}{l}\mathrm{Cu}, \\
\mu \mathrm{g} \mathrm{L}^{-1}\end{array}$} & A & 0.7 & 1.22 & 1.46 & 1.87 & 1.05 & 272 & 79 & 89 & 0.48 & 0.67 \\
\hline & B & 0.09 & $<0.03$ & 0.04 & 0.83 & $<0.03$ & 224 & 25.38 & 11.58 & $<0.03$ & $<0.03$ \\
\hline & C & 1.98 & 1.86 & 2.26 & 3.94 & 0.67 & 349 & 201.9 & 204.7 & 2.41 & 2.52 \\
\hline \multirow{3}{*}{$\begin{array}{c}\mathrm{Fe}, \\
\mu \mathrm{g} \mathrm{L}^{-1}\end{array}$} & A & 2.22 & 1.85 & 1.85 & 0.37 & 0.37 & 0.9 & 4.44 & 2.22 & 1.48 & 1.86 \\
\hline & B & 2.21 & 2.11 & 1.71 & 1.65 & 2.1 & 0.8 & 2.33 & 2.31 & 2.53 & 1.65 \\
\hline & C & 2.27 & 2.28 & 2.03 & 2.03 & 0.9 & 0.81 & 1.53 & 1.45 & 2.2 & 2.27 \\
\hline \multirow{3}{*}{$\begin{array}{l}\mathrm{Mn}, \\
\mu \mathrm{g} \mathrm{L}^{-1}\end{array}$} & A & 2.16 & 2.6 & 1.25 & 2.14 & 0.25 & 52 & 13.05 & 13.6 & 0.04 & 0.08 \\
\hline & B & 3.71 & 7.12 & 1.7 & 2.31 & 0.19 & 45 & 0.53 & 0.39 & 0.07 & 0.1 \\
\hline & C & 6.52 & 2.64 & 1.8 & 4.65 & 0.20 & 56 & 23.18 & 24.67 & 0.16 & 0.2 \\
\hline \multirow{3}{*}{$\begin{array}{c}\mathrm{Ni}, \\
\mu \mathrm{g} \mathrm{L}^{-1}\end{array}$} & $\mathbf{A}$ & 3.35 & 3.2 & 2.93 & 2.69 & 3.52 & 13.6 & 7.22 & 7.11 & 3.92 & 1.65 \\
\hline & B & 1.36 & 1.41 & 0.95 & 1.04 & 1.18 & 10.1 & 1.5 & 1.37 & 1.37 & 1.52 \\
\hline & C & 2.03 & 1.95 & 1.52 & 1.7 & 3.35 & 12.1 & 7.03 & 6.75 & 1.64 & 1.76 \\
\hline \multirow{3}{*}{$\begin{array}{l}\mathrm{Pb}, \\
\mu \mathrm{g} \mathrm{L}^{-1}\end{array}$} & A & 0.04 & 0.05 & 0.42 & 0.48 & 0.07 & 66 & 26.95 & 29.91 & 0.17 & 0.17 \\
\hline & B & 0.15 & 0.1 & 0.42 & 0.42 & 0.47 & 68 & 10.38 & 7.1 & 0.1 & 0.09 \\
\hline & C & 0.65 & 0.54 & 0.73 & 0.74 & $<0.03$ & 63 & 28.1 & 30.6 & 1.03 & 0.66 \\
\hline \multirow{3}{*}{$\begin{array}{l}\text { Se, } \\
\mu \mathrm{g} \mathrm{L}^{-1}\end{array}$} & A & 0.03 & 0.03 & $<0.02$ & 0.03 & 0.02 & 0.06 & $<0.02$ & $<0.02$ & $<0.02$ & $<0.02$ \\
\hline & B & $<0.02$ & $<0.02$ & $<0.02$ & $<0.02$ & $<0.02$ & 0.12 & 0.09 & 0.12 & 0.24 & 0.20 \\
\hline & C & 0.2 & 0.4 & 0.31 & 0.41 & $<0.02$ & 0.41 & 0.48 & 0.38 & 0.65 & 0.67 \\
\hline \multirow{3}{*}{$\begin{array}{c}\mathrm{V}, \\
\mu \mathrm{L}^{-1}\end{array}$} & A & 0.17 & 0.22 & 0.07 & 0.12 & 0.05 & 0.06 & $<0.03$ & $<0.03$ & 0.05 & 0.06 \\
\hline & B & 0.34 & 0.37 & 0.13 & 0.18 & 0.11 & 0.07 & 0.08 & 0.09 & 0.13 & 0.13 \\
\hline & C & 0.53 & 0.27 & 0.09 & 0.19 & 0.04 & 0.06 & 0.06 & 0.06 & 0.11 & 0.1 \\
\hline \multirow{3}{*}{$\begin{array}{c}\mathrm{Zn}, \\
\mu \mathrm{g} \mathrm{L}^{-1}\end{array}$} & $\mathbf{A}$ & 7.28 & 6.79 & 7.02 & 8.49 & 10.31 & 124 & 132.5 & 60.33 & 5.65 & 8.9 \\
\hline & B & $<0.05$ & $<0.05$ & $<0.05$ & $<0.05$ & 2 & 115 & 78.3 & $<0.05$ & $<0.05$ & 6.3 \\
\hline & C & 1.58 & 0.97 & 2.11 & 5.34 & 12.09 & 136 & 101.8 & 67.72 & 3.04 & 28.62 \\
\hline $\mathrm{RSD}^{*}, \%$ & & $2-5$ & $2-8$ & $3-7$ & $3-8$ & $4-8$ & $2-5$ & $1-6$ & $2-7$ & $2-8$ & $2-9$ \\
\hline
\end{tabular}

${ }^{*} \mathrm{RSD}$ values range for all determinations of the element 
Trace element content and physicochemical parameters of independent sources 5 and 13 (in the case when not in use to [10] power drinking water supply) and sources $6,7,8,12,14$ and 15 have to meet the requirements set out in the ordinance. All tested independent sources meet the statutory values, except for the source 14. This source is located near the mine shaft used for ore extraction and $\mathrm{Pb}$ concentrations measured are almost 9 times higher than permissible limit of $10 \mu \mathrm{g} \mathrm{L}^{-1}$.

In order to obtain more complete characterization of waters in this region several elements not mention in regulatory documents but existing and determined in copper ore were measured: Mo, Sr, Th, TI, Se, Y, Be and lanthanides. The values for the elements $\mathrm{TI}, \mathrm{Y}$ and Be were below $0.5 \mu \mathrm{g} \mathrm{L}^{-1}$ for all studied sampling sites and close to their background levels. Only for element Sr were found relatively high concentrations from 90 to $340 \mu \mathrm{g} \mathrm{L}^{-1}$, which however is close to the natural levels of this element in surface waters in the region. The content of lanthanides all are below $<0.03 \mu \mathrm{g} \mathrm{L}^{-1}$, except $\mathrm{Eu}$, for which $0.03 \mu \mathrm{g} \mathrm{L}^{-1}$ were found in sample 3 in a first campaign (A). The probable explanation for the absence of these elements in waters in the region is that most likely they exist in the rocks and ores as slightly soluble or insoluble compounds.

\section{CONCLUSIONS}

All of the values for physicochemical parameters are below the permissible limits accepted as a national standard for drinking waters.

Results of chemical analysis show dependence between the hydrological regime and element concentration - the concentrations are statistically significantly lower for sampling campaign B in comparison with campaigns A and $C$.

Results obtained for priority pollutants $(\mathrm{Cd}, \mathrm{Hg}, \mathrm{Ni}$ and $\mathrm{Pb})$ and specific pollutants (Al, As, $\mathrm{Cr}, \mathrm{Cu}, \mathrm{Fe}, \mathrm{Mn}, \mathrm{U}$ and $\mathrm{Zn}$ ) for surface waters sources are good. Exception is sampling point 13, when it have elevated concentrations measured for priority pollutants $\mathrm{Cd}$ and $\mathrm{Pb}$ and specific pollutants $\mathrm{Cu}$ and $\mathrm{Zn}$.

It was obtained, that values for all other chemical elements in drinking waters showed no deviation from the permissible limits, except the element $\mathrm{Pb}$.

All tested independent sources meet the statutory values, except for the source 14, when the $\mathrm{Pb}$ concentrations measured are almost 9 times higher than permissible limit of $10 \mu \mathrm{g} \mathrm{L}^{-1}$. 


\section{EXPERIMENTAL SECTION}

\section{Materials and methods}

\section{Characteristics of sampling sites}

The sampling points were carefully chosen to represent the influence of various factors such as, industrial activities in the past, and other anthropogenic pressures on the quality of surface and drinking waters. The sampling points are presented in Fig. 1.1 and 2 sampling points sequentially situated on river Bovska; 13 - spring of river Treskavets, used for drinking water; 3- sampling point on river Treskavets; 4 - sampling point on river Treskavets after the merger of river Bovska; 5, 6, 7, 8, 12, 14 and $15-$ sampling points representing local springs, used for drinking water, but not included in village water supplies; 9 and 16 sampling points from drinking water supply 2; 10 and 11 sampling points from drinking water supply 1 .

Three sampling campaign (SC) were performed in different seasons: summer 2012 (A) - relatively high waters (high rains one month before sampling), spring 2013 (B) - high waters (high rains in the period); autumn 2013 (C) - dry period (no any rains one months before sampling). In order to remove direct influence of rain water the sampling is performed in a period without rain at least $24 \mathrm{~h}$ before sampling.

The water supply 1 is feeded from the spring at sampling point 13 for the sampling campaigns $A$ and $C$ and from the spring at sampling point 5 for campaign $B$. The water supply 2 is feeded from spring at sampling point 6 for all sampling campaigns performed.

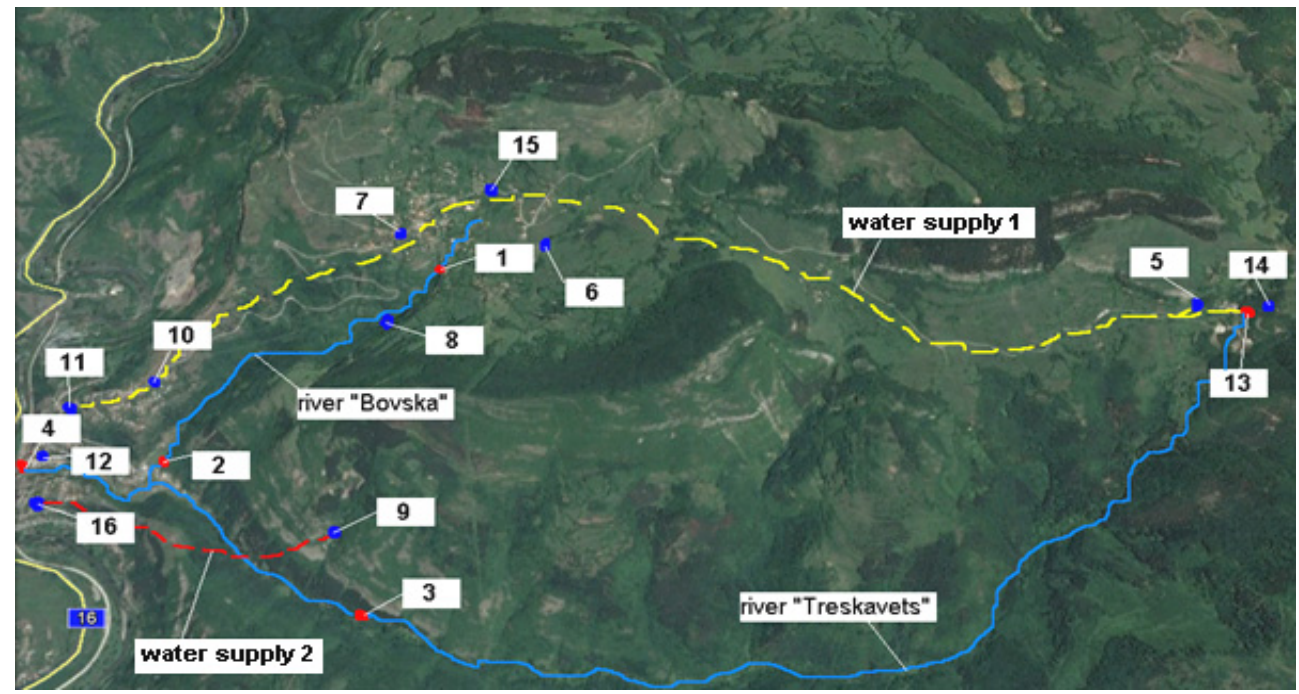

Figure 1. Region map with sampling points. 


\section{Sample collection and handling}

For the determination of physicochemical parameters water samples were collected by grabsampling in polyethylene plastic bottles of $1.5 \mathrm{~L}$, previously rinsed with $4 \%$ nitric acid and then with MilliQ water. For the determination of trace metals, clean procedures were strictly followed through all experiments. Water samples of $100 \mathrm{ml}$ were collected by grabsampling, immediately were filtered through $0.45 \mu \mathrm{m}$ - cellulose membrane filters (Millipore) and acidified with $0.5 \mathrm{~mL}$ concentrated $\mathrm{HNO}_{3}$ (Baker, Suprapur) until $\mathrm{pH}$ 2. All samples were kept at $4{ }^{\circ} \mathrm{C}$ in a dark place before laboratory analysis.

\section{Apparatus}

Inductively coupled plasma-mass spectrometry measurements were carried out on mass spectrometer "X SERIES 2" - Thermo Scientific. Conductivity measurements and $\mathrm{pH}$ determinations were performed with combined $\mathrm{pH}$ meter "PCE-PHD1" - PCE instruments.

\section{Reagents}

High-purity reagents (Merck and Fluka Analytical), $\mathrm{HNO}_{3}(65 \%$ suprapur, Merck, Darmstadt, Germany) and Milli-Q water $\left(0,01 \mu \mathrm{S} . \mathrm{cm}^{-1}\right)$ were used for all experiments. Quality control material for surface waters SPS-SW1 Surface Level 1 (Spectrapure Standards AS, Oslo, Norway) was used as additional calibrant. Certified Reference Material SLRS-5 (River Water Reference Material for Trace metals), National Research Council Canada was used for quality control of analytical results.

\section{Analytical procedures}

Physicochemical parameters: $\mathrm{pH}$, conductivity, hardness, chemical oxygen demand $\left(\mathrm{COD}_{\mathrm{KMnO}}\right)$; biological oxygen demand $\left(\mathrm{BOD}_{5}\right)$; dissolved oxygen; dissolved solids; suspended matter; dry residue; chlorides; sulphates; nitrates and phosphates were determined according to the standard analytical procedures, accepted in national standards [17-29].

Concentrations of chemical elements (Al, As, Ba, Cd, Cr, Co, Cu, $\mathrm{Fe}, \mathrm{Hg}, \mathrm{Mn}, \mathrm{Ni}, \mathrm{Se}, \mathrm{U}, \mathrm{V}$ and $\mathrm{Zn}$ as well as lantanides were determined by inductively coupled plasma-mass spectrometry under optimal instrumental parameters. 


\section{REFERENCES}

1. Directive 2000/60/EC of the European Parliament and of the Council, Framework for Community action in the field of water policy, 23 october 2000.

2. Directive $98 / 83 / E C$ of 3 November 1998 on the quality of water intended for human consumption.

3. ZI. Zlatev, Precursory Paper of EIA (Environment Impact Assessment). Technical-economic Investigation about Improvement of Environment Safety for "Eliseina" Copper Works in Republic of Bulgaria. Baugrund Institute KNIRIM - Ltd, Sofia, 1996, chapter 3.

4. St. Stoyanov, Heavy Metals in the Environment and the Foodstuffs. Poisonous Influence on the Human. Clinical Pattern. Medical Treatment and Prophylaxis. PSSA, Sofia, 1999, chapter 4 (in Bulgarian).

5. I. Gruev, D. Petkova, V. Valkov, Environment Impact Assessment Report of "Eliseina" JSC (Object in Exploitation). Scientific Research Center at UCTMSofia, 1999 (in Bulgarian).

6. I. Gruev, Assessment of the Impact of Old Contaminations at the "Eliseina" JSC. Scientific Research Center at UCTM-Sofia, 1999, chapter 2.

7. I. Stoyanov, Assessment of the Impact of Old Contaminations at the "Eliseina" JSC - Stage 3. Geoecoconsult, Sofia, 2002.

8. SGRB (State Gazette of Republic of Bulgaria) Regulation №H-4/14.09.2012 for characterization of surface waters. State Gazette 22/05.03.2013 (in Bulgarian).

9. SGRB (State Gazette of Republic of Bulgaria), Regulation №12/18.02.2002 for quantities requirements for surfaces waters used for drinking purposes. State Gazette 63/28.06.2002 (in Bulgarian).

10. SGRB (State Gazette of Republic of Bulgaria), Regulation №9/16.03.2001 for quality of drinking waters. State Gazette 30/28.03.2001 (in Bulgarian).

11. X. Hao, D. Wang, P. Wang, Y. Wang, D. Zhou, Environmental monitoring and assessment, 2016, 188, 24.

12. T. Sevidik, E. Altundal, F. Kucuk, Ekoloji, 2015, 24(97), 14.

13. T. Stafilov, T.B. Balabanova, B.R. Sajn, D. Rokavec, Variability Assessment for Lithogenic and Anthropogenic Distribution of Trace and Macroelements in Water, Sediment and Soil Samples. Case Study: Bregalnica River Basin, Republic of Macedonia, Nova Science Publishers, Inc. In: Advances in Environmrntal Research, 2015, Volume 43, Chapter 6, Editor: Justin A. Daniels.

14. O. Arkoc, Journal of Environmental Protection and Ecology, 2011, 12(4), 1644.

15. M. Rasheed, P. Rao, B. Radha, M. Lakshmi, A. Dayal, Journal of Environmental Protection and Ecology, 2011, 12(2), 425.

16. A. Giouri, M. Vavelidisa, V. Melfosa, C. Christophoridis, Journal of Environmental Protection and Ecology, 2010, 11(2), 424.

17. BNS 17.1.4.27:1980 Environmental protection. Hydrosphere. Indicators for water quality. Method for $\mathrm{pH}$ measurement (in Bulgarian).

18. BNS EN 27888:2000 Water quality - Determination of electrical conductivity. 
19. BNS 3775:1987 Drinking water. Method for determination of total hardness (in Bulgarian).

20. BNS 17.1.4.24:1980 Environmental protection. Hydrosphere. Indicators for water quality. Method for determination of chlorides (in Bulgarian).

21. BNS EN ISO 6878:2005 Water quality - Determination of phosphorus Ammonium molybdate spectrometric method.

22. BNS 17.1.4.12:1979 Environmental protection. Hydrosphere. Indicators for water quality. Method for determination of nitrates (in Bulgarian).

23. BNS ISO 7150-1:2002 Water quality - Determination of ammonium - part 1. Manual spectrometric method (in Bulgarian).

24. BNS 17.1.4.02:1977 Environmental protection. Hydrosphere. Indicators for water quality. Method for determination of oxidizability (in Bulgarian).

25. BNS EN 1899-2:2004 Water quality - Determination of biochemical oxygen demand after after $\mathrm{n}$ days (BODn) - Part 2: Method for undiluted samples (ISO 5815:1989, modified).

26. BNS 17.1.4.16:1979 Environmental protection. Hydrosphere. Indicators for water quality. Method for determination of chemical oxygen demand (in Bulgarian).

27. BNS 17.1.4.03:1977 Environmental protection. Hydrosphere. Indicators for water quality. Method for determination of sulphates (in Bulgarian).

28. BNS 17.1.4.08:1978 Environmental protection. Hydrosphere. Indicators for water quality. Method for determination of dissolved oxygen content (in Bulgarian).

29. BNS 17.1.4.04:1980 Environmental protection. Hydrosphere. Indicators for water quality. Method for determination of dry residue, suspended matter and dissolved solids (in Bulgarian). 